\title{
Optimal vegetation management under mul- tiple-use objectives in the Cross Timbers
}

\author{
D.J. BERNARDO, D.M. ENGLE, R.L. LOCHMILLER, AND F.T. MCCOLLUM
}

\begin{abstract}
Authors are associate professor, Agricultural Economics Department: professor. Agronomy Department: associate professor, Zoology Department; and associate professor, Animal Science Department, Oklahoma State University, Stillwater.
\end{abstract}

\begin{abstract}
The relatively low productivity of the herbaceous stratum of the oak-hickory forests of North America has prompted land managers to evaluate alternative means of increasing large herbivore production. A mathematical programming model was developed to evaluate alternative vegetation management programs for large herbivore production in the Cross Timbers Region of the Ozark Plateaus. The optimization determined the combination of livestock enterprises, lease-hunting enterprises, and vegetation management practices that maximized discounted net returns over a 15-year period. Results indicated that by integrating both herbicides and prescribed fire into vegetation management programs, sufficient herbivory can be sustained to support an economically viable level of livestock production. Vegetation management programs derived under multiple-enterprise objectives differ significantly from those in conjunction with a single enterprise. Economic returns from cattle production are maximized by applying herbicides that induce large increases in grass production, and thus, allow for significant expansion of the cattle enterprise. Under multiple-enterprise objectives, 2 herbicides and prescribed burning may be integrated effectively to sustain sufficient production of grasses, forbs, and browse to support expanded cattle, Angora goat, and white-tailed deer populations. Economic returns from the land resource can be increased approximately $46 \%$ as a result of employing multiple-enterprise management objectives.
\end{abstract}

Key Words: brush management, oak-hickory forest, post oak (Quercus stellata Wang.), blackjack oak ( $Q$. marilandica Muenchh.), white-tailed deer (Odocoileus virginianus), multipleuse management, economic analysis, optimization models

The Cross Timbers, an important yet largely unrecognized land resource, occupies the western edge of the oak-hickory forest on the Ozark Plateaus (Garrison et al. 1977, Daubenmire 1978, Walter 1985). The Ozark Plateaus comprise nearly 20 million ha of the 125 million ha eastern forest of the United States (Garrison et al. 1977, Office of Technology Assessment [OTA] 1982). Land ownership in the region is predominantly private. Because the timber resource does not support an economically viable industry, economic activity has largely been restricted to cattle grazing on marginal production units (Byington et al. 1983).

The relatively low productivity of the herbaceous stratum of these forests has prompted cattle producers and policy makers in the United States to consider land conversion and intensive forage production practices to increase cattle carrying capacity (Burton 1973, OTA 1982). Approaches to increasing large herbivore production and the economic value of these lands include management of existing vegetation to produce desired vegetation (Scifres et al. 1983) and using 2 or more species of large herbivore to

This is journal article $\mathrm{J}-6153$ of the Oklahoma Agricultural Experiment Station. Manuscript accepted 31 Dec. 1991 improve efficiency of forage harvest (Cook 1985). Foliage-applied and soil-applied herbicides can increase the production of herbaceous vegetation in the Cross Timbers up to six-fold by reducing competition from overstory hardwoods (Elwell et al. 1974, Engle et al. 1991). However, the desired vegetation structure is usually short-lived, and follow-up treatments, traditionally with repeat application of herbicides or prescribed fire, are required to maintain the results derived with the initial herbicide treatment (Scifres et al. 1983). Additional production alternatives include the adoption of alternative livestock and lease-hunting enterprises. Although lease-hunting is a relatively new phenomenon in the region, indicators point to significant increases in the value of hunting rights over the next decade (Porter 1987). As a result, wildlife management objectives will become increasingly important in vegetation management decision making. Information is needed to assist resource managers in developing integrated vegetation management programs, including the timing and type of range investments, as well as accompanying livestock and wildlife enterprises.

Previous analyses of vegetation management in the Cross Timbers have focused on benefits accruing to a single cattle enterprise (Bernardo et al. 1991, Engle 1988, McCollum et al. 1987). Bernardo et al. (1991) evaluated 6 alternative brush management strategies using herbicides and prescribed burning to reduce hardwoods in the Cross Timbers. Benefits derived from vegetation treatment were limited to increases in the weight gain and stocking rate of summer stocker cattle grazing the treated areas. Because increases in livestock numbers were estimated based upon the allocation of additional grass production, prescriptions from the model favored herbicides prompting the largest increase of grass production. However, vegetation management practices most conducive to beef cattle production do not necessarily result in vegetation best suited for alternative enterprises. This potential conflict between cattle production and other enterprises provides the impetus for reevaluating range improvement programs in the region.

The objective of this study was to develop and compare economically efficient vegetation management programs under both cattle production and multiple-enterprise management objectives. The degree to which multi-species grazing and wildlife lease-hunting influence optimal range improvement decisions was ascertained from the analysis.

\section{Method of Analysis}

A multi-year linear programming model was developed to derive economically efficient vegetation management programs under multiple-enterprise objectives. ${ }^{1}$ The objective of the optimization model was to determine the combination of livestock enterprises,

IFor additional detail concerning model specification and underlying data, the reader is referred to Department of Agricultural Economics Paper AE-2567, Department of Agricultural Economics, Oklahoma State University, Stillwater, Oklahoma. 
lease-hunting enterprises and vegetation management practices for reducing hardwood competition that maximizes the sum of discounted net returns over a 15 -year planning horizon. The multiyear model consisted of a series of annual production submodels linked by a set of relationships that defined changes in forage and financial resources over time in response to vegetation management and stocking decisions.

Annual production submodels were specified to allocate limited resources, specifically forage, capital, and labor, among the competing enterprises so as to maximize discounted annual net returns. Two principle types of activities were included in each of the annual models: (1) vegetation management activities which resulted in increases in forage in the year initiated and subsequent years of the planning horizon, and (2) livestock and wildlife enterprises which utilized annual forage production.

Annual net cash $\left(\mathrm{NCF}_{t}\right)$ were estimated as the sum of net returns from the livestock and lease-hunting enterprises less vegetation management costs. That is,

$$
N C F_{t}=\sum_{j=1}^{s} c_{j} X_{j t}+p_{t}\left(D_{t}\right) A-\sum_{k=1}^{r} \mathbf{v}_{\mathbf{k}} Y_{k t}
$$

where,
$\mathrm{X}_{\mathrm{jt}}=$ number of head of livestock enterprise produced in year $\mathrm{t}$
$c_{j}=$ net return from livestock enterprise $\mathbf{j}, \$ /$ head
$\mathbf{Y}_{\mathbf{k t}}=$ land area treated with vegetation management prac- tice $k$ in year $t$, ha
$v_{k}=$ cost of vegetation management practice $k, \$ /$ ha
$\mathrm{p}_{\mathrm{t}}=$ value of lease-hunting trespass rights in year $\mathrm{t}(\$ / \mathrm{ha})$, expressed as a function of white-tailed deer pop- ulation in year $t\left(D_{t}\right)$

$A=$ total range land area, ha

Objective function coefficients for the livestock enterprises were per-head net return estimates, calculated as gross receipts less variable production costs. Returns from the lease hunting enterprise were calculated as the product of the lease-hunting rate $(\$ / \mathrm{ha})$ and the total land area. The lease-hunting rate was estimated as a function of deer population density.

The forage base was divided into 3 forage classes: grasses, forbs, and browse. To reflect the changing availability of these forage classes within a year, annual forage production was divided into 4 subperiods (or seasons). Annual forage production was allocated to livestock and wildlife enterprises through a series of forage balance equations.

$$
\begin{aligned}
& \sum_{j=1}^{s} a_{j}^{k} X_{j t}+d_{i}^{R} D_{t}-\sum_{m=1}^{t} \sum_{k=1}^{r} w_{i k m}^{R} Y_{k m}-c_{i t}^{g}+u_{i t}^{k}<0(i=1,2,3,4) \\
& \stackrel{s}{\Sigma} a_{j}^{f} X_{j t}+d_{i}^{f} D_{t}-\stackrel{t}{\Sigma} \quad \stackrel{r}{\Sigma} w_{i k m}^{f} Y_{k m}-G_{i t}^{f}+u_{i t}^{f}<0(i=1,2,3,4) \\
& j=1 \quad m=1 \quad k=1 \\
& \stackrel{s}{\sum} a_{i j}^{b} X_{j t}+d_{i}^{b} D_{t}-\stackrel{t}{\sum} \quad \sum_{k} w_{i k m}^{b} Y_{k m}-c_{i t}^{b}+u_{i t}^{b}<0(i=1,2,3,4) \\
& \mathrm{j}=1 \\
& m=1 \quad k=1
\end{aligned}
$$

where:

$$
\begin{aligned}
& \mathbf{a}_{\mathrm{ij}}, \mathbf{a}_{\mathrm{ij}}^{\mathrm{f}}, \mathbf{a}_{\mathrm{ij}}^{\mathrm{b}}=\text { forage utilization (grasses, forbs, } \\
& \text { and browse, respectively) by live- } \\
& \text { stock enterprise } j \text { in subperiod } i \\
& d_{i}^{\mathbb{q}}, d_{i}^{f} d_{i}^{b}=\text { forage utilization (grasses, forbs, and } \\
& \text { browse, respectively) by deer in sub- } \\
& \text { period } \mathrm{i} \\
& w_{i k m}^{k}, w_{k m}^{f}, w_{i k m}^{b},=\text { available forage production (grasses, }
\end{aligned}
$$

period $\mathrm{i}$ in year $\mathrm{t}$ carried over from period i-1

$u_{i t}^{\mathrm{g}}, u_{\mathrm{it}}^{\mathrm{f}}, \mathrm{u}_{\mathrm{it}}^{\mathrm{b}}=$ unutilized forage (grasses, forbs, and browse, respectively) in period i of year $t$

Equations 2 to 4 represent forage balance equations for grasses, forbs, and browse in each of the 4 subperiods of each year. Total quantity of forage consumed by livestock and white-tailed deer (Odocoileus virginianus) was calculated in the first and second terms of the equation, while the third term represented the quantity of forage produced in the period available for consumption by livestock and wildlife. The forage balance equations assured that total utilization of each forage class did not exceed the sum of production and forage carryover from the previous period. Forage that was not utilized in a subperiod was carried over to subsequent subperiods through a set of forage decay functions. These relationships determined the quantity of unused forage carried over from the previous subperiod $\left(u_{i-1}\right)$ available for utilization in the following subperiod $\left(c_{i}\right)$ and take the form:

$$
c_{i}=a\left(u_{i-1}\right)
$$

By changing the parameter " $a$ " in equation 5 , unique forage decay functions were specified for grasses, forbs, and browse and for each set of adjoining subperiods. The model does not represent any interaction between utilization and forage production.

The set of annual production models were linked through the objective function and a series of relationships defining the transition of production and financial variables across years. The objective function of the multi-period model was specified as:

$$
\sum_{t=15}^{n} N_{i}(1+r)^{-1}
$$

where, $r$ is the discount rate and $n$ is the number of years in the planning horizon. Long-term forage response to vegetation management was represented through the technical coefficients of the range investment activities. These coefficients ( $w_{\text {ikm }}$ 's in equations 2 to 4 ) indicated forage production in the treatment year, as well as all subsequent years of the treatment's life.

\section{Data}

The model was developed to derive economically efficient vegetation management programs and accompanying livestock enterprises for a representative 2,000-ha commercial ranch in the Cross Timbers of central Oklahoma. The forage resource was assumed to be comprised of equal proportions of shallow savannah and sandy savannah range sites, dominated by an overstory of post oak (Quercus stellata Wang.) and blackjack oak ( $Q$. marilandica Muenchh.) (Ewing et al. 1984). Forage production potential was greater on the sandy savannah site because of the deeper soils and run-in topographic position.

\section{(4) Vegetation Management and Forage Response}

Vegetation management options included in the analysis were: (1) tebuthiuron (N-[5-1,1-dimethylethyl-1,3,4-thiadiazol-2-yl]-N, N'-dimehylurea), (2) tebuthiuron followed by annual spring burning, (3) triclopyr ([3,5,6-tricloro-2-pyridinyl oxy] acetic acid), and (4) triclopyr followed by annual spring burning. Application rates of $2.2 \mathrm{ai} / \mathrm{ha}$ were used for both herbicides. These selective herbicides induced regression toward tallgrass prairie on both shallow and sandy savannah range sites, but tebuthiuron produced a more complete and longer-term suppression of hardwood competition. Prescribed burning, which provided secondary reduction of resistant and resprouting woody plants, has been found to be more effective following tebuthiuron than triclopyr (Stritzke et al. 1991).

The ranch was divided into 20 equal-sized management units, 10 dominated by shallow savannah range sites and 10 comprised 
primarily of sandy savannah sites. Vegetation management alternatives were evaluated annually on each management unit, and chemical treatments and prescribed burns were applied to entire 100-ha pastures to prevent the inclusion of unrealistically small annual treatments.

Vegetation management effects were incorporated into the analysis via forage response curves developed to represent changes in grass, forb, and browse production resulting from each treatment strategy. The response curves (Figs. 1a through 1d) depicted the path of expected seasonal standing crop over the time horizon of the analysis. Peak standing crop for 8 years following application of each practice were actual standing crop measurements from a study in the Cross Timbers (Engle et al. 1991 and unpublished data). Peak standing crop in the remaining years of each practice's life represented a consensus of "expert opinion" projections based on 3 decades of research results in the Cross Timbers of Oklahoma (Elwell et al. 1974, Stritzke et al. 1975, Engle et al. 1991).

Previous studies on seasonal standing crops of grasses and forbs in nearby tallgrass prairie (Powell et al. 1979, Powell et al. 1982a, Powell et al. 1982b, Ewing and Engle 1988), and of browse in the Cross Timbers (Johnson and Risser 1974) were used to set respective grass standing crops in winter, spring, and fall at 30,70 , and $75 \%$ of summer standing crop. Forb standing crops in winter, spring, and fall were set at 20,70 , and $30 \%$, and browse standing crops in winter, spring, and fall were set at 30,100 , and $50 \%$ of summer standing crop. The annual decay function, or the percentage of grass and forb production carried over into subsequent subperiods, were derived from data on litter and mulch disappearance and production in the tallgrass prairie (Sims and Singh 1978, Branson 1985). No portion of browse standing crop was transferred to subsequent years based on the assumption that deadfall leaf and twig litter and second-year twig growth did not constitute available browse. Twenty-five percent of peak standing crop of grass and forb herbage was allocated to consumption (Kothmann 1984). Peak standing crop was increased by $15 \%$ to adjust for the difference in peak standing crop and net primary production on tallgrass prairie (Powell et al. 1982a).

\section{Livestock and Lease-Hunting Enterprises}

Both fall-calving and spring-calving cow-calf systems were evaluated. Calves were weaned at an age of 210 days at weights of 204 and $198 \mathrm{~kg}$ for steer and heifer calves, respectively. A death loss of $2 \%$ for mature cows during winter months was assumed, as well as an $88 \%$ weaning rate (Walker et al. 1987). To prevent unrealistic fluctuations in the size of the cow herd over time, changes in cow numbers were not permitted to exceed $15 \%$ per year.

Stocker production alternatives included season-long (SLS) and intensive-early stocking (IES). Season-long steers were purchased at a weight of $200 \mathrm{~kg}$ in mid-April and grazed for 150 days. IES steers were purchased in mid-April and grazed for 80 days. Average daily gains were $.7 \mathrm{~kg}$ for SLS and $1.0 \mathrm{~kg}$ for IES. Summer gains of stocker cattle increased $10-20 \%$ in response to spring burning (McCollum et al. 1987); therefore, average daily gains of stocker cattle grazing burned pastures were increased to $.8 \mathrm{~kg}$ and $1.2 \mathrm{~kg}$ for SLS and IES steers, respectively.

The goat production alternative was an Angora goat nanny enterprise. Each goat production unit consisted of a doe, 0.2 yearling does, and 0.03 bucks. Production from the goat enterprise included adult mohair, kid mohair, kids, and cull does. Production costs and performance data were developed from information provided by area producers and Scrivner and Conner (1984). A $75 \%$ kid crop was assumed, with a death loss of $8 \%$ for adult goats and $14 \%$ for kids. Like the cow-calf enterprises, adjustments in the size of the goat herd were limited to $15 \%$ annually.

Daily forage demand ( $\mathrm{kg}$ intake/head/day) by goats and cattle was calculated from diet digestibility, estimated from the contribu-
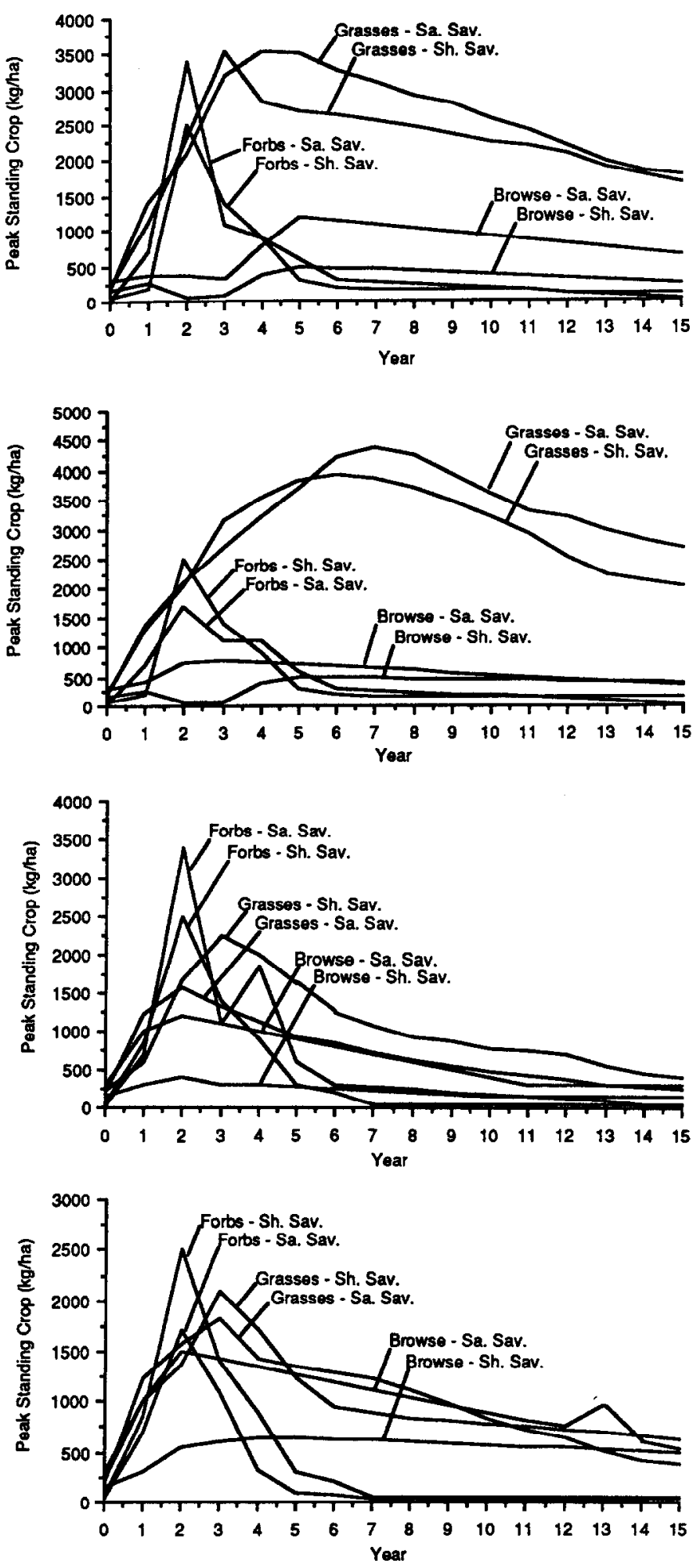

Fig. 1a. Grass, forbs, and browse response curves for tebuthiuron treatment on shallow and sandy savannah range sites.

Fig. 1b. Grass, forbs, and browse response curves for tebuthiuron treatment followed by annual prescribed burning on shallow and sandy savannah range sites.

Fig. 1c. Grass, forbs, and browse response curves for triclopyr treatments on shallow and sandy savannah range sites.

Fig. 1d. Grass, forbs, and browse response curves for triclopyr treatment followed by annual prescribed burning on shallow and sandy savannah range sites. 
tion of grass, forbs, and browse in the diet of each livestock class, and from daily fecal output (FO), according to the following equation (Fernandez-Rivera et al. 1989):

$$
\mathrm{FO}=.0365 \mathrm{~W}^{.75}
$$

where

$\mathrm{W}=$ animal weight $(\mathrm{kg} /$ head$)$.

Although this relationship was developed from cattle trials, intake estimates for goats were within the expected range (National Research Council 1981). Daily forage intake was estimated as the quotient of daily fecal output divided by diet in-digestibility. Forage intake estimates for lactating females were increased by $25 \%$ during the lactation period. Daily intake of individual forage classes was calculated as the product of daily forage intake and percent contribution to the diet by each forage class. To incorporate the influence of vegetation management practices on livestock intake and diet composition, separate livestock production activities were included for animals grazing herbicide treated, burned, and untreated pastures.

Forage consumption is reported by season for each livestock enterprise in Table 1. Seasonal diets were estimated from studies on digestibility values for each forage class (Bogle et al. 1989), and cattle diets (McCollum unpubl. data) previously conducted on Cross Timbers rangeland that had been treated with 1 of the 4 vegetation management options referenced earlier. Goat diet information was obtained from studies conducted in treated and untreated post oak savannah of central Texas (Lopes and Stuth 1984) and untreated, climax oak-hickory forest of central Arkansas (Child et al. 1985).

The population of white-tailed deer was assumed to adjust through reproduction and immigration to levels consistent with forage availability; however, a maximum population density of 4 ha/deer was assumed. A harvest rate of $20 \%$ per year was assumed if hunting leases were in effect. To assure realistic adjustments in deer population over time, changes in deer numbers were restricted to a maximum of $15 \%$ per year. Dry matter intake requirements for white-tailed deer were estimated from data reported by Wheaton and Brown (1983). Seasonal increases in intake of 30 to $60 \%$ were made for does during gestation and lactation. Intake requirements reflect an average deer weight of $45 \mathrm{~kg}$ and a doe:buck ratio of 2:1. The seasonal diets of white-tailed deer in the Cross Timbers obtained from Vreede (1987) were used to distribute total subperiod intake among grasses, forbs, and browse (Table 1).

\section{Costs, Returns, and Economic Situations}

Application and chemical costs for the chemical treatments were $\$ 160.00 /$ ha for tebuthiuron and $\$ 86.45 /$ ha for triclopyr, while the annual costs of prescribed burning was estimated at $\$ 6.23 / \mathrm{ha}$ (Engle 1988). Since triclopyr and tebuthiuron treatments affected rangeland profitability beyond the 15 -year time horizon, the residual value of each treatment was incorporated into the model. Residual (or terminal) values of each treatment were estimated based upon the discounted value of the remaining forage production and varied depending upon the remaining life of the treatment. Since all costs and returns were expressed in real terms, a real discount rate of $6 \%$ was utilized in the analysis.

Costs of production for the various livestock enterprise were estimated from enterprise budgets reported in Bernardo and McCollum (1987), Scrivner and Conner (1984), and Walker et al. (1987). Expected livestock prices employed in the analysis represented averages of monthly prices (indexed to 1990) for each livestock class from the Oklahoma City Livestock Market over a 5 -year period. Returns from livestock enterprises were estimated as gross receipts less variable costs and are reported in Table 2.

The impact of vegetation management on the value of hunting leases is not known. Currently, the value of white-tailed deer lease-hunting rights in the Cross Timbers Region ranges from $\$ 1.85 /$ ha to $\$ 4.95 /$ ha, depending upon the quality of the wildlife habitat (Porter 1987). A linear relationship was developed between the population density of white-tailed deer and the value of trespass rights for hunting, assuming the lease rate was $\$ 1.85 /$ ha at the baseline deer population and reached its maximum value at the maximum population density (4 ha/deer). Thus, lease-hunting revenues were responsive to improvements in wildlife habitat introduced by vegetation management practices.

Moderate capital constraints were imposed in each of the scena-

Table 1. Predicted seasonal intake by forage class in the Cross Timbers.

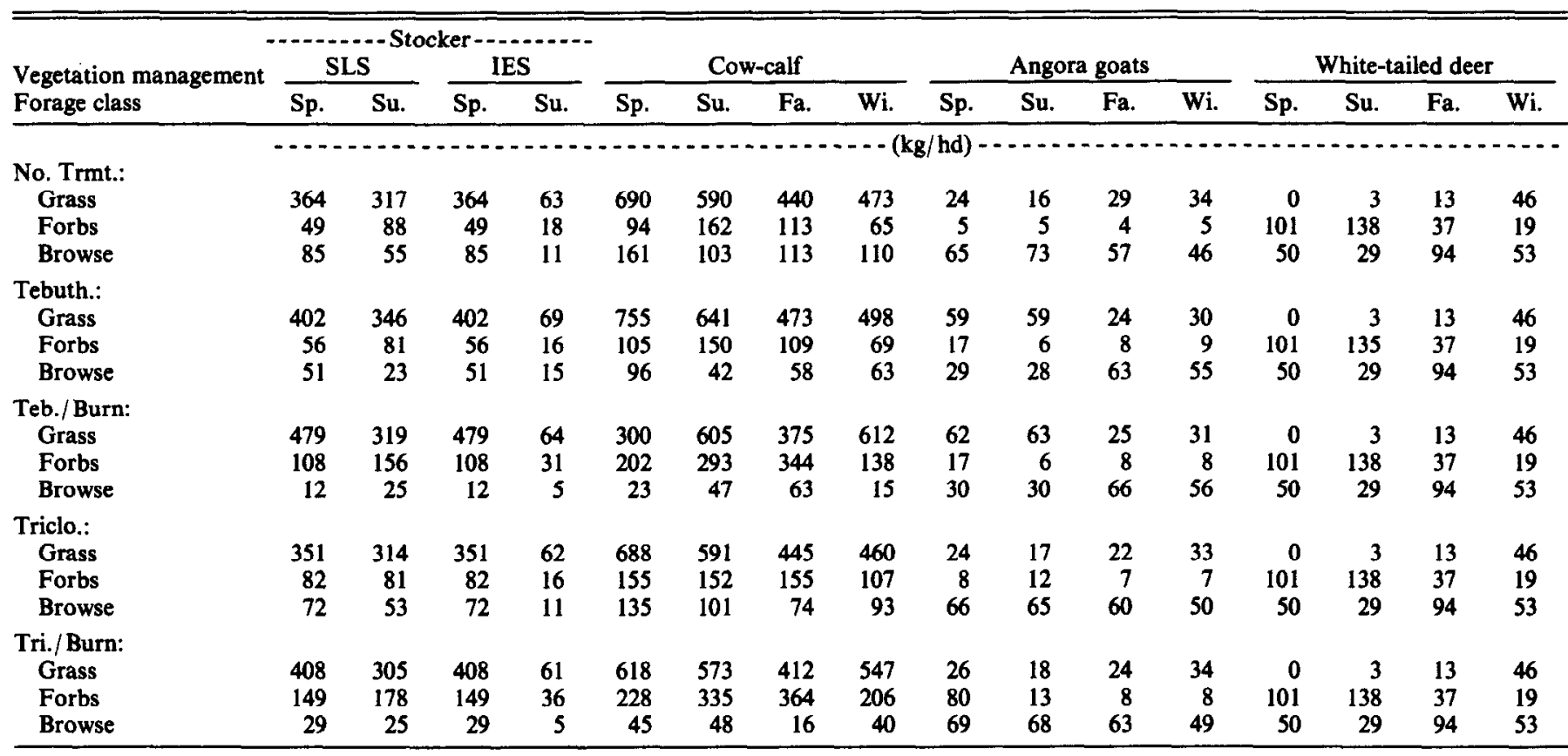


Table 2. Livestock enterprise revenues, costs, and net returns used in developing the optimal vegetation management programs.

\begin{tabular}{lccc}
\hline \hline Enterprise & $\begin{array}{c}\text { Total } \\
\text { revenue }\end{array}$ & $\begin{array}{c}\text { Production } \\
\text { cost }\end{array}$ & $\begin{array}{c}\text { Net } \\
\text { return }\end{array}$ \\
\hline Season-long steers (unburned) & $\$ 568.21$ & $\$ 531.80$ & $\$ 36.41$ \\
Season-long steers (burned) & 581.13 & 536.19 & 44.94 \\
Early-season steers (unburned) & 525.66 & 506.33 & 19.33 \\
Early-season steers (burned) & 538.41 & 510.11 & 28.30 \\
Cow-calf (spring calving) & 349.08 & 282.76 & 66.32 \\
Cow-calf (fall calving) & 378.24 & 321.02 & 57.22 \\
Angora goats & 74.56 & 58.13 & 16.43 \\
\hline
\end{tabular}

rios. Based upon financial surveys of livestock producers in the area, an initial debt-asset ratio of 0.30 was selected (total assets = $\$ 500,000$ and total liabilities $=\$ 150,000)$. Chemical treatments required a $20 \%$ down payment, while the remaining balance could be financed with a 5-year debt. The amount of capital available each year for investment was limited to a quantity that prevented the debt-asset ratio from exceeding 0.50 , thus eliminating the possibility of treating all available land area in the initial year of the planning horizon. Since income variability has been found to increase significantly following vegetation management investments, the treatment of all available land area in a single year would not likely be adopted by risk averse decision makers (Bernardo and Engle 1990).

\section{Results and Discussion}

Two scenarios were developed to evaluate the influence of multiple-use objectives on optimal vegetation managements programs. In the first scenario, livestock production was limited to grazing season-long stockers. All livestock enterprises included in the model (season-long stockers, intensive-early stockers, cowcalf, and Angora goats), as well as the white-tailed deer leasehunting enterprise, were available in the second scenario. By comparing the 2 solutions, the effect that multi-species grazing and wildlife habitat considerations had on vegetation management decisions were ascertained. The sensitivity of optimal range improvement programs to alternative cattle prices, lease-hunting rates and excluding the possibility of goat production was then considered.

\section{Single Enterprise Scenario}

The vegetation management plan derived when production was limited to a single stocker enterprise is summarized in Table 3. The vegetation management practices employed and the number of season-long stockers grazed are reported for each year of the planning horizon. Each of the 10 shallow and sandy savannah management units was assigned a number; for example, TEB 1-7 implies tebuthiuron was applied on pastures 1 through 7 of the given range site. White-tailed deer population was limited to a base with a density of $25 \mathrm{ha} /$ head; however, no revenues were generated from lease-hunting.

Vegetation treatments adopted in the optimal plan included application of tebuthiuron and tebuthiuron followed by annual prescribed burning. In year $1,70 \%$ of sandy savannah area was treated with tebuthiuron. Annual prescribed burning was employed on these management units in subsequent years to provide secondary reduction of resprouting and resistant woody plants. Tebuthiuron followed by annual prescribed burning provided the greatest forage response of the vegetation management investments evaluated. Sandy savannah was treated first since grass production potential was greatest on this range site (Fig. 1a). The remaining 3 sandy savannah management units were treated in years 2 and 4 ,
Table 3. Optimal vegetation management treatments practices and livestock enterprises under single enterprise objectives.

\begin{tabular}{rllc}
\hline \hline Year & Sandy savannah & $\begin{array}{l}\text { Shallow } \\
\text { savannah }\end{array}$ & $\begin{array}{c}\text { Season-long } \\
\text { steers }\end{array}$ \\
\hline 1 & TEB 1-7 & - & 142 \\
2 & TEB 8, B 1-7 & TEB 1-5 & 586 \\
3 & B 1-8 & TEB 6 & 810 \\
4 & TEB 9-10, B 1-8 & -- & 1441 \\
5 & B 1-8 & TEB 7 & 1675 \\
6 & B 1-8 & - & 1853 \\
7 & B 1-8 & TEB 8-9 & 1934 \\
8 & B 1-8 & TEB 10 & 1979 \\
9 & B 1-8 & - & 1809 \\
10 & B 1-8 & -- & 1756 \\
11 & B 1-8 & - & 1631 \\
12 & TEB 1-2, B 1-8 & - & 1421 \\
13 & B 1-8 & - & 1389 \\
14 & TEB 3, B 1-8 & - & 1351 \\
15 & B 1-8 & - & 1308 \\
\hline
\end{tabular}

TEB = single application of te buthiuron $(2.2 \mathrm{~kg} / \mathrm{ha}), \mathrm{B}=$ prescribed burning. Each of the 10 shallow savannah and sandy savannah management units are assigned a pasture number. For example, TEB $1-7$ indicates tebuthiuron is applied in pastures 1 through 7.

but did not receive secondary control through prescribed burning. Retreatment of these 3 units occurred in years 12 and 14.

Treatment of shallow savannah range sites began in year 2 and continued through year 9 , until all 10 management units were treated. Follow-up treatment with prescribed burning was unprofitable on the shallow savannah range site. In an earlier study conducted on the identical range site, Bernardo et al. (1991) found a single application of tebuthiuron followed by annual burning provided the highest return of the 4 range improvement alternatives. This earlier study, however, did not account for changes in the diet intake of steers grazing tebuthiuron-treated pastures burned annually, which exceeded steer intake on unburned pastures by approximately $15 \%$ (Table 1 ). This result indicated that assuming identical intake levels across all treatments may underestimate the carrying capacity of the land and the profitability of prescribed burning.

Adjustments in livestock numbers over the 15-year planning horizon corresponded closely to changes in forage response following the vegetation management treatments. The initial stocking density ( $14 \mathrm{ha} / \mathrm{steer}$ ) reflected the low herbage production of the untreated sites. Steer numbers increased throughout the first 8 years of the planning horizon, reflecting increases in carrying capacity provided by the treatments. Stocking densities were increased to levels as high as $1 \mathrm{ha} /$ steer when the ranch's total production of forage was maximized in year 8 . Grass response curves for treatments initiated in years 1 through 3 reached their apex by year 8 ; small reductions in total herbage production occurred in subsequent years. Total steer numbers followed this trend in the latter years of the planning horizon, declining in years 9 through 12 , then leveling off in the final 3 years. Forage availability was relatively stable in years 13 through 15 as a result of retreatment of a portion of the sandy savannah area and secondary control provided by prescribed burning.

Discounted net returns from stocker production over the 15year time horizon totaled $\$ 266,000$. Annual net cash flow estimates for the ranch averaged approximately $\$ 36,400$ (or $\$ 18.20 /$ ha). Net cash flows varied considerably because of the large expenses incurred in years when substantial areas were herbicide treated and because of subsequent changes in forage production. For example, in the first year $\$ 116,000$ in vegetation management expenses were incurred, resulting in an annual net cash flow of $-\$ 77,100$. Annual net cash flows reached levels as high as $\$ 81,200$ during the period of maximum forage production. 


\section{Multiple-Enterprise Scenario}

Vegetation management strategies derived under multipleenterprise objectives were considerably more complex than those prescribed for the single enterprise scenario. Vegetation management treatments and accompanying enterprise combinations for each year of the planning horizon are presented in Table 4. As in

Table 4. Optimal vegetation management treatments and livestock enterprises under multiple-enterprise objectives.

\begin{tabular}{|c|c|c|c|c|c|c|}
\hline \multirow[b]{2}{*}{ Year } & \multirow{2}{*}{$\begin{array}{l}\text { Sandy } \\
\text { savannah }\end{array}$} & \multirow{2}{*}{$\begin{array}{l}\text { Shallow } \\
\text { savannah }\end{array}$} & \multicolumn{4}{|c|}{ Livestock Enterprises $^{b}$} \\
\hline & & & Goats & SLS & IES & Deer \\
\hline & & & \multicolumn{4}{|c|}{$\ldots$} \\
\hline 1 & TEB $1-4^{a}$ & TEB $1-5$ & 535 & 30 & & 80 \\
\hline 2 & TEB 5-7, B 1-4 & B $1-5$ & 618 & 363 & & 92 \\
\hline 3 & B 14 & B $1-5$ & 707 & 594 & & 106 \\
\hline 4 & B $1-4$ & TEB $6-7$, B $1-5$ & 695 & 865 & 206 & 122 \\
\hline 5 & TEB 8, B 1-4 & & 799 & 1247 & 267 & 140 \\
\hline 6 & & , B $1-5$ & 919 & 1452 & 286 & 161 \\
\hline 7 & TRI 9, B $1-4$ & B $1-5$ & 1050 & 1550 & 384 & 185 \\
\hline 8 & TRI 10, B $1-4$ & $9-10$, B $1-5$ & 1211 & 670 & 1418 & 200 \\
\hline 9 & B $1-4$ & B $1-5$ & 1392 & 655 & 1371 & 178 \\
\hline 10 & B $1-4$ & B 1-5 & 1486 & 585 & 1348 & 167 \\
\hline 11 & TRI 1, B 2-4 & B $1-5$ & 1510 & 480 & 1350 & 149 \\
\hline 12 & TRI 2, B 3-4 & B $1-5$ & 1501 & 304 & 1121 & 126 \\
\hline 13 & B 3-4 & B $1-5$ & 1525 & 317 & 1180 & 107 \\
\hline 14 & TRI 3-4 & B $1-5$ & 1465 & 341 & 1021 & 110 \\
\hline 15 & & TRI 1-2, B 2-5 & 1420 & 333 & 965 & 103 \\
\hline
\end{tabular}

TEB = single application of tebuthiuron $(2.2 \mathrm{~kg} / \mathrm{ha}), \mathrm{TRI}=$ single application of triclopyr $(2.2 \mathrm{~kg} / \mathrm{ha}), \mathrm{B}=$ prescribed burning. Each of the 10 shallow savannah and sandy savannah management units are assigned a pasture number. For example, TEB sandy savannah management units are assigned a pasture num

1-7 indicates tebuthiuron is applied in pastures 1 through 7.
${ }^{b}$ SLS = season-long summer stocker steers, IES = intensive-early stocking steers.

the vegetation management program under cattle-only enterprise, a large portion of the total land area was treated with tebuthiuron during the initial stages of the planning horizon. In this case, however, both shallow savannah and sandy savannah management units were treated in the first year. Nine management units were treated in year 1 with tebuthiuron. Secondary control through prescribed burning and triclopyr were employed on these units in subsequent years of the planning horizon.

Although triclopyr treatments resulted in considerably less grass production than tebuthiuron, triclopyr provided greater quantities of forb and browse production in early portions of the treatment's life. While this attribute had little value in the production of stockers, it did provide an important portion of the forage base for goats and white-tailed deer. Triclopyr was applied as an initial treatment on both shallow and sandy savannah range sites, as well as a retreatment of management units treated initially with tebuthiuron. Approximately $40 \%$ of the land area treated with tebuthiuron in year 1 was retreated with triclopyr in the latter 5 years of the planning horizon.

The introduction of multiple-enterprise objectives also affected the use of prescribed burning as a means of reducing resprouting hardwoods. Prescribed burning was employed less intensively on sandy savannah sites than in the vegetation management plans derived for stocker production. Application of tebuthiuron without follow-up burning promoted a more diverse mix of browse, forbs, and grasses than when tebuthiuron was followed with annual burning (Fig. 1b).

Compared to the single enterprise alternative, improved efficiency of utilization of the forage base occurred as a result of the adoption of the additional enterprise alternatives. As in the singleenterprise solution, stockers were grazed at low stocking rate during the initial year of the planning horizon. In this case, however, the livestock plan also included a moderately sized Angora goat herd. Although the goat enterprise primarily consumed the browse component of the forage base which had been largely unutilized in the previous solution, some consumption of forbs and grass by the goats did occur. As a result of this competition for available forage, the total number of steers grazed in the initial year was lower than in the single enterprise management plan. Neither cow-calf enterprise was included in the optimal livestock plans, reflecting the year-long enterprises' inefficient utilization of grass production (in terms of dollars per pound of forage) relative to grazing summer stockers. This result is consistent with previous studies of the region which indicated a dominance of stocker production when forage is limited to native ranges (Rockeman and Walker, Rawlins and Bernardo). Sensitivity analysis revealed that net returns from cow-calf production would need to increase approximately $\$ 21.00$ per cow unit before the spring-calving enterprise would begin entering the optimal production plans.

Livestock numbers were adjusted over the 15-year time horizon in response to changes in total forage production, as well as changes in the composition of forbs, browse, and grass. As in the single-enterprise scenario, increases in the number of steers grazed annually closely followed grass production increases provided by the initial tebuthiuron treatments. The total number of steers produced increased from 30 to 2,088 head over the first 8 years of the planning horizon. Stocker production was split between season-long and intensive-early stocking enterprises. Intensiveearly stocking enterprises were primarily produced on pastures that were burned annually to take advantage of early-season increases in forage quality. The optimal management plan also involved gradually increasing the size of the goat herd over the first 10 years of the analysis. The goat herd expanded in response to increased browse and grass availability, then remained relatively stable over the latter portion of planning horizon. Triclopyr treatments occurring in the latter portion of the time horizon provide sufficient browse production (see Fig. lc and 1d) to maintain a relatively large goat enterprise over the planning period.

The population density of white-tailed deer ranged between 10 and $25 \mathrm{ha} /$ deer, and averaged approximately $15 \mathrm{ha} /$ deer over the 15-year planning period. Deer encountered considerable competition for forage from cattle and goats, particularly in the spring and summer periods; therefore, their population corresponded closely to the response of forbs following the vegetation treatments. The deer population increased from its initial size through immigration and reproduction over the first half of the planning horizon. White-tailed deer numbers reached a maximum at 200 head, a herd size $21 / 2$ times the initial level. Deer number decreased in response to reduction in forb production occurring over latter portions of a treatment life; however, retreatment of pastures provided sufficient forb production to maintain a deer herd larger than the initial size.

Discounted returns for the 15-year time horizon totaled $\$ 388,000$. Discounted net returns were increased by $\$ 122,000(46 \%)$ as a result of employing multiple-enterprise management objectives. Following initial negative net cash flows resulting from large expenditures for vegetation treatments, annual cash flows increased in conjunction with changes in livestock numbers. Annual net cash flow reached a maximum in year 10 at a level of $\$ 93,300$ $(\$ 46.65 / \mathrm{ha})$. Annual net cash flows for the ranch averaged approximately $\$ 41,300$ under multiple-enterprise management.

\section{Alternative Scenarios}

The slow development of lease-hunting in Oklahoma is reflected by a relatively low current market value of trespass rights for hunting. In this scenario, lease-hunting rates were doubled to determine how vegetation management decisions were affected when a higher priority was placed on wildlife management objectives. Optimal vegetation management plans were similar to those reported in Table 4; however, a greater emphasis was placed on vegetation management practices providing additional production 
of forbs. Because triclopyr provided significant increases in the availability of forbs relative to tebuthiuron, this treatment was employed on several management units treated with tebuthiuron in the baseline scenario.

The size of both the stocker and goat enterprises were reduced marginally relative to livestock numbers reported in Table 4. In contrast, the white-tailed deer population was shown to expand significantly in response to the increased availability of forbs and reduced competition from livestock. The deer herd increased over the first 10 years of the analysis, reaching a maximum size of 305 head, then leveled off to a size of about 200 head during the latter third of the 15-yr horizon. The average deer density was about 9 ha/deer over the planning horizon, approximately $50 \%$ higher than the average population in the baseline scenario. Discounted returns increased $14 \%$ above the baseline level.

Because producers may not wish to use Angora goats as a potential enterprise, a plan which eliminated the goat enterprise was considered. As in the baseline solutions, both tebuthiuron, triclopyr, and prescribed burning were employed in the optimal vegetation management plan. As a result of reduced competition from the goats, deer numbers increased markedly over levels reported in Table 4 . The average deer density was about 8 ha/deer, nearly double the level derived when goats were produced. Stocking rates of steer enterprises were increased about $10 \%$ above levels reported in Table 4. Discounted net returns were decreased $21 \%$ as a result of excluding the Angora goat enterprise.

To evaluate the effect that a long-run decrease in cattle prices would have on vegetation management, the model was run with cattle prices reduced $25 \%$ below baseline levels. Vegetation management and accompanying enterprises were shown to be relatively sensitive to livestock prices. Tebuthiuron was applied on approximately half of the sandy savannah acreage in year 1 , while the remaining sandy savannah acreage received triclopyr applications in subsequent years. No returns occurred, and shallow savannah sites were not treated. Total AUMs allocated to cattle were reduced by an average of $40 \%$ relative to levels reported in Table 4 . Angora goats and deer accounted for a larger proportion of total AUMs than in the baseline solution, but did not increase in total number. This decline occurred because of the reduced productivity resulting from the substitution of triclopyr for tebuthiuron and absence of vegetation management on several management units.

\section{Summary and Conclusions}

Through the development of efficient vegetation management programs, land managers of the Cross Timbers' deciduous forests can significantly increase the production of large herbivores. By integrating both herbicides and prescribed fire into vegetation management programs, sufficient herbivory can be sustained to support an economically viable level of livestock production. In addition, multi-species grazing can increase the harvest efficiency of primary production and improve the profitability of vegetative management practices.

Vegetation management programs derived under multipleenterprise objectives differed significantly from those to be used in conjunction with a single cattle enterprise. Economic returns from stocker production were maximized with either a single application of tebuthiuron or a single application of tebuthiuron followed by annual prescribed burning, depending on range site. These treatments provided large increases in grass production and allowed for significant expansion of the stocker enterprises over the life of the treatment. Under multiple-enterprise objectives tebuthiuron, triclopyr, and prescribed burning were applied over the 15-year planning horizon. In addition to increasing grass production, triclopyr treatments augmented the availability of browse and forbs for consumption by Angora goats and white-tailed deer.
Thus, areas treated with tebuthiuron, triclopyr, and prescribed burning sustained sufficient herbivory to support expanded livestock enterprises (stockers and Angora goats) as well as a larger white-tailed deer population.

The results of these analyses must be interpreted in light of the assumptions employed. Limited data are available from which to specify relationships defining forage production, diet composition, and livestock performance following a vegetation treatment. In addition, little is known concerning adjustments in white-tailed deer diet and population following vegetation management practices in the Cross Timbers. Application of the model to different sites, initial vegetatation, ranch firm organizations and economic situations would require respecification of the model and would likely result in different efficient vegetation management programs. However, production relationships employed in this study are adequate to illustrate the types of differences that exist between vegetation management programs developed under multipleenterprise objectives and those derived solely for cattle grazing.

\section{Literature Cited}

Bernardo, D.J., and D.M. Engle. 1990. The effect of manager risk attitudes on range improvement decisions. J. Range Manage. 43:243-248.

Bernardo, D.J., D.M. Engle, and F.T. McCollum. 1988. An economic assessment of risk and returns from prescribing burning on tallgrass prairie. J. Range Manage. 41:178-183.

Bernardo, D.J., and F.T. McCollum. 1987. An economic analysis of intensive-early stocking. Oklahoma Agr. Exp. Sta. Res. Rep. P-887.

Benardo, D.J., F.T. McCollum, D.M. Engle, and J.F. Stritzke. 1991. An economic evaluation of brush management programs in the Cross Timbers. In: T. Bidwell (ed.) OSU range research highlights: 1980-1991. Oklahoma Coop. Ext. Serv. Stillwater, Okla.

Bogle, L.A., D.M. Engle, and F.T. McCollum. 1989. Nutritive value of range plants in the Cross Timbers. Oklahoma Agr. Exp. Sta. Res. Rep. P-908.

Branson, F.A. 1985. Vegetation changes on western rangelands. Range Mongr. No. 5, Soc. Range Manage., Denver, Colo.

Burton, G.W. 1973. Integrating forest trees with improved pastures. p. 41-49. In: Range resources of the southeastern United States. Amer. Soc. Agron. Spec. Pub. 21.

Byington, E., D. Child, N. Byrd, H. Dietz, S. Halverson, H. Pearson, and F. Horn. 1983. Management of southern U.S. farms for livestocking grazing and timber production on forested farmlands and associated pasture and range lands. Winrock Internat., Morrtilton, Ark. 60 p.

Child, R.D., E.K. Byington, and H.H. Hansen. 1985. Goats in the mixed hardwoods of the southeastern United States, p. 149-158. In:F.H. Baker and R.K. JOnes (eds.) Proc. Conf. on Multispecies Grazing. Winrock Internat. Morrilton, Ark.

Cook, C.W. 1985. Opportunities to increase multispecies grazing in the eastern United States. p. 7-25. In: F.H. Baker and R.K. Jones (eds.) Proc. Conf. on Multispecies Grazing. Winrock Internat., Morrilton, Ark.

Daubenmire, R. 1978. Plant geography. Academic Press, Inc. N.Y.

Elwell, H., P.W. Santelmann, J.F. Stritzke, and H. Greer. 1974. Brush control research in Oklahoma. Okla. Agr. Exp. Sta. Bull. B-712.

Engle, D.M. 1988. Burning costs in Oklahoma rangelands. Rangelands. 10:135-137.

Engle, D.M., J.F. Stritzke, and F.T. McCollum. 1991. Vegetation management in the Cross Timbers: Response of understory vegetation to herbicides and burning. Weed Tech. 5:406-410.

Ewing, A.L., and D.M. Engle. 1988. Effects of late summer fire on tallgrass prairie microclimate and community composition. Amer. Midl. Natur. 120:212-223.

Ewing, A.L., J.F. Stritzke, and J.D. Kulbeth. 1984. Vegetation of the Cross Timbers Experimental Range, Oklahoma. Okla. Agr. Exp. Sta. Res. P-856.

Fernandez-Rivera, S., M. Lewis, T.J. Klopfenstein, and T.L. Thompson. 1989. A simulation model of forage yield quality and intake and growth performance of growing cattle grazing cornstalks. J. Anim. Sci.

Garrison, G.A., A.J. Bjugstad, D.A. Duncan, M.E. Lewis, and D.R. Smith. 1977. Vegetation and environmental features of forest and range ecosystems. USDA, Forest Serv. Agr. Handb. 475. 
Johnson, F.L., and P.G. Risser. 1974. Biomass annual net primary production, and dynamics of six mineral elements in a post oak-blackjack oak forest. Ecology 55:1246-1258.

Kothmann, M.M. 1984. Concepts and principles underlying grazing systems. p. 903-916. In: NRC/NAS, Developing strategies for rangeland management. Westview Press. Boulder, Colo.

Lopes, E.A., and J.W. Stuth. 1984. Dietary selection and nutrition of spanish goats as influenced by brush management. J. Range Manage. 37:554-57.

McCollum, M.K., D.M. Engle, and J.F. Stritzke. 1987. p. 110-113. In: Brush management on the Cross Timbers Experiment Range: III. Carrying capacity and steer performance. Oklahoma Agr. Exp. Sta. MP-119.

National Research Councll. 1981. Nutrient requirements of goats. Nat. Acad. Press. Washington, D.C.

Office of Technology Assessment. 1982. Impacts of technology on U.S. cropland and rangeland productivity. Congress of the United States. Washington, D.C.

Porter, M.D. 1987. Lease hunting in Oklahoma. p. 21-22. In: Proc. Lease Hunting: Pros and Cons. Kansas State University Coop. Ext. Serv. Manhattan, Kan.

Powell, J., F.R. Crow, and D.G. Wagner. 1982a. Rangeland watershed budget and grazing cattle nutrient cycling. U.S. Environ. Protection Agency. Ada, Okla.

Powell, J., D.R. Hake, G.L. Dunn, and J.K. McPherson. 1982b. Effect of grassland management on range condition, runoff, and water quality. Final Rep. for Oklahoma State University/USDA-ARS. Stillwater, Okla.

Powell, J., H.T. Zawi, J.J. Crockett, L.I. Croy, and R.D. Morrison. 1979. Central Oklahoma rangeland response to fire, fertilization and grazing by sheep. Oklahoma Agr. Exp. Sta. Bull. B-744.
Rawlins, R.B., and D.J. Bernardo. Incorporating uncertainty in the analysis of optimal beef-forage production systems. So. J. Agr. Econ. 23:213-25.

Rockeman, K.A., and O.L. Walker. 1979. Range-cropland pasture utilization systems for Oklahoma ranches. Current Farm Economics. 52:7 20.

Scifres, C.J., W.T. Hamilton, J.M. Inglis, and J.R. Connor. 1983. Development of integrated brush management systems (IBMS): Decisionmaking process. p. 97-104. In: K.C. McDaniel (ed.) Proc. Brush Management Symp. Soc. Range Manage. Denver, Colo.

Scrivner, J.H., and J.R. Conner. 1984. Costs and returns from Angora goat enterprises with and without predation. J. Range Manage. 37:166-171.

Sims, P.L., and J.S. Singh. 1978. The structure and function of ten western North American grasslands. IV. Compartmental transfers and energy flow within the ecosystem. J. Ecol. 66:983-1009.

Stritzke, J.F., W.E. McMurphy, and R.W.Hammond. 1975. Brush control with herbicides: Sarkey's research and development report. Oklahoma Agr. Exp. Sta. MP-95.

Stritzke, J.F., D.M. Engle, and F.T. McCollum. 1991. Vegetatation management in the Cross Timbers: Response of woody species to herbicides and burning. Weed Tech. 5:400-405.

Vreede, G.V. 1987. Seasonal diets of white-tailed deer in south-central Oklahoma. M.S. Thesis, Texas Tech Univ., Lubbock.

Walker, O.L., K.S. Lusby, and W.E. McMurphy. 1987. Beef and pasture systems for Oklahoma. Okla. Agr. Exp. Sta. Res. Rep. P-888.

Walter, H. 1985. Vegetation of the earth and ecological systems of the geobiosphere. Third ed. Springer-Verlag, Berlin.

Wheaton, C., and R.D. Brown. 1983. Feed intake and digestive efficiency of south Texas white-tailed deer. J. Wildlife Manage. 47:442-450.

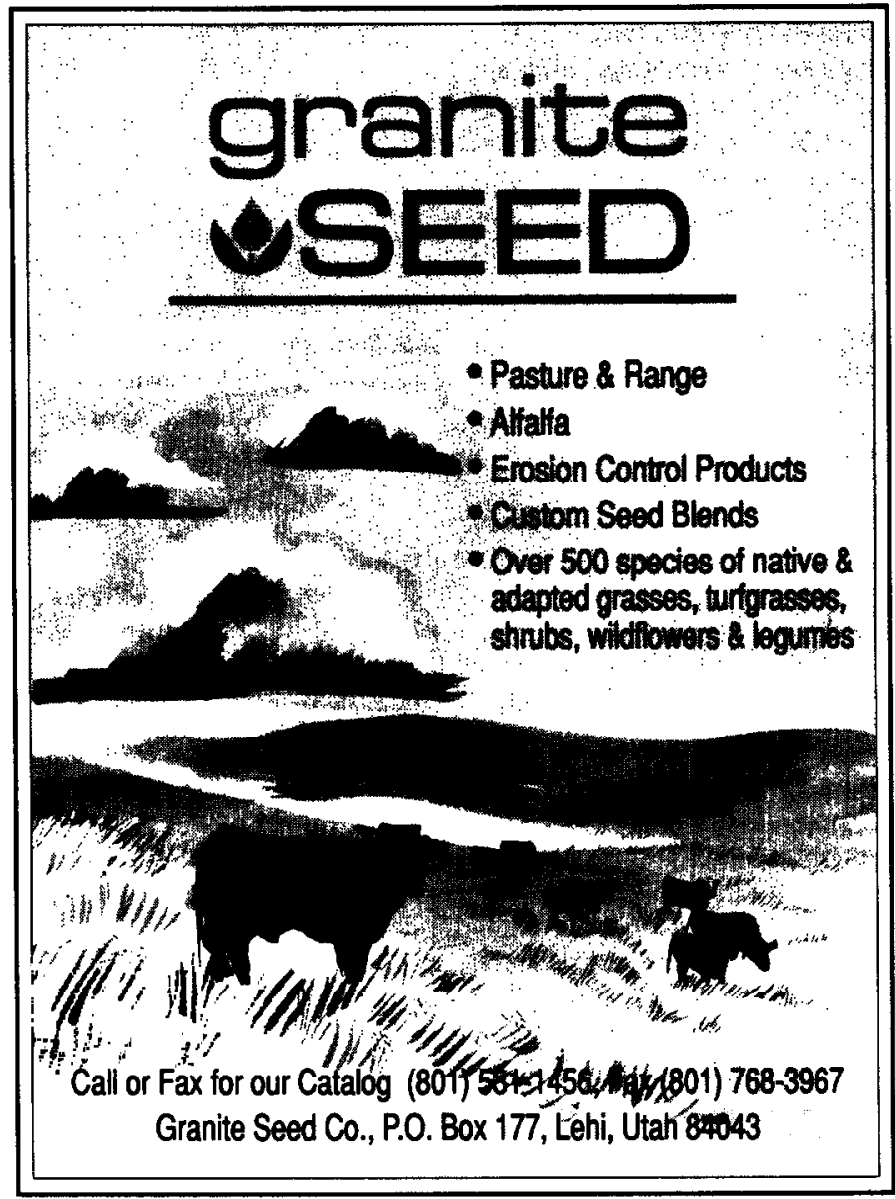

